\title{
Putting the Success Stories of the Postcommunist World into a Broader Perspective
}

\author{
Vladimir Popov*
}

March 2009

\begin{abstract}
Why many transition economies succeeded by pursuing policies that are so different from the radical economic liberalization (shock therapy) that is normally credited for the economic success of central European countries? First, optimal policies are context dependent, they are specific for each stage of development and what worked in Slovenia cannot be expected to work in Mongolia. Second, even for countries at the same level of development, reforms needed to stimulate growth are different; they depend on the previous history and on the path chosen. The reduction of government expenditure as a share of GDP did not undermine significantly the institutional capacity of the state in China, but in Russia and other CIS states it turned out to be ruinous. It is the growth diagnostics that should reveal the missing ingredient for economic growth. Finally, and most important, introducing this 'missing ingredient' should not result in the destruction of other preconditions for growth. The art of the policymaker is to create markets without causing the government failure, as happened in many CIS countries.
\end{abstract}

Keywords: transition, growth diagnostics, path dependence

JEL classification: O43, O57, P27, P52

Copyright (C) UNU-WIDER 2009

* New Economic School, Moscow, email: vpopov@NES.RU and EURUS, Carleton University, Ottawa, email:vpopov@ccs.carleton.ca

This study has been prepared within the UNU-WIDER project on Country Role Models for Development Success, directed by Augustin Fosu.

UNU-WIDER gratefully acknowledges the financial contributions to the project by the Finnish Ministry for Foreign Affairs, and the financial contributions to the research programme by the governments of Denmark (Royal Ministry of Foreign Affairs), Finland (Finnish Ministry for Foreign Affairs), Norway (Royal Ministry of Foreign Affairs), Sweden (Swedish International Development Cooperation AgencySida) and the United Kingdom (Department for International Development). 


\section{Acronyms}

CIS Commonwealth of Independent States

EBRD European Bank for Reconstruction and Development

IPRs intellectual property rights

LA Latin America

SA South Asia

SEZs special economic zones

SSA Sub-Sahara Africa

TVEs township and village enterprises

The World Institute for Development Economics Research (WIDER) was established by the United Nations University (UNU) as its first research and training centre and started work in Helsinki, Finland in 1985. The Institute undertakes applied research and policy analysis on structural changes affecting the developing and transitional economies, provides a forum for the advocacy of policies leading to robust, equitable and environmentally sustainable growth, and promotes capacity strengthening and training in the field of economic and social policy making. Work is carried out by staff researchers and visiting scholars in Helsinki and through networks of collaborating scholars and institutions around the world.

www.wider.unu.edu

publications@wider.unu.edu

UNU World Institute for Development Economics Research (UNU-WIDER)

Katajanokanlaituri 6 B, 00160 Helsinki, Finland

Typescript prepared by Liisa Roponen at UNU-WIDER

The views expressed in this publication are those of the author(s). Publication does not imply endorsement by the Institute or the United Nations University, nor by the programme/project sponsors, of any of the views expressed. 


\section{Stylized facts}

As Leo Tolstoy claimed in Anna Karenina, 'happy families are all alike; every unhappy family is unhappy in its own way'. This wisdom, however, can be hardly applied to the development success of countries: it appears that success stories in the development and transition world are as different as they can be. It is not uncommon to come across contradictory statements about the reasons of economic success: economic liberalization and free trade are said to be the foundations of rapid growth in some countries, whereas successes of other countries are credited to industrial policy and protectionism; foreign direct investment (FDI) that is normally considered as a factor contributing to growth, did not play any significant role in the developmental success of Japan, South Korea and pre-1990s China. Privatization of state enterprises, foreign aid, immigration, liberalization of the financial system, democratic political institutions - all actors, just to name a few, that are usually believed to be prerequisites of successful development, but it is easy to point out to success stories not associated with these factors.

In the 1970s the breathtaking economic success of Japan that transformed itself into a developed country just in two postwar decades was explained by the 'Japan incorporated' structure of the economy-special relations between the government and companies (MITI), between banks and non-financial companies (bank-based financial system), between companies and workers (lifetime employment). After the stagnation of the 1990s, and especially after the 1997 Asian financial crisis that affected Japan as well, these same factors were largely labelled as clear manifestations of 'crony capitalism' that should be held responsible for the stagnation.

Similar patterns can be observed in transition countries, from Vietnam and China to former East Germany and Albania. Obviously what worked in some countries, did not work in others. Three central European countries-Czech Republic, Hungary and Poland-are claimed to be success stories of transition (together with Slovenia and Slovak Republic — and to a lesser extent, other East European countries). The success is attributed to the elimination of soft budget constraints (subsidies to state and non-state enterprises), openness to trade and FDI-in the case of Czech Republic; to the 'strategic role of foreign investors, especially in the banking sector and in the process of Europeanization, understood as a two-way social learning process' - in the case of Hungary; Poland is said to have had just a relative success, achieving only two-thirds of its potential performance. 1

But there are other examples of successes in the region as well. Suffice it to look at the graphs below to realize that in the transition world, as elsewhere, 'success' (at least as measured by the growth of GDP) is not always associated with economic liberalization and democracy. In 1989-2006, Turkmenistan was doing better than Poland; and Uzbekistan and Belarus - no worse than Hungary and Czech Republic (Figure 1). And whereas former Soviet Union states experienced on average a steeper and more lasting decline in output during the transformational recession of the 1990s (Figure 2), their speed of economic recovery was, in many instances, higher than that of central

1 Polish shock therapy strategy is actually criticized and it is argued that Poland could have achieved more with a more gradual policy (changing things little by little) and a 'mix of two policies-a system change policy and a development policy’. 
European countries. In 2000-07 average annual growth rates of GDP in Azerbaijan were 15 per cent, in Armenia, Kazakhstan, and Turkmenistan-over 10 per cent (Figure 3).

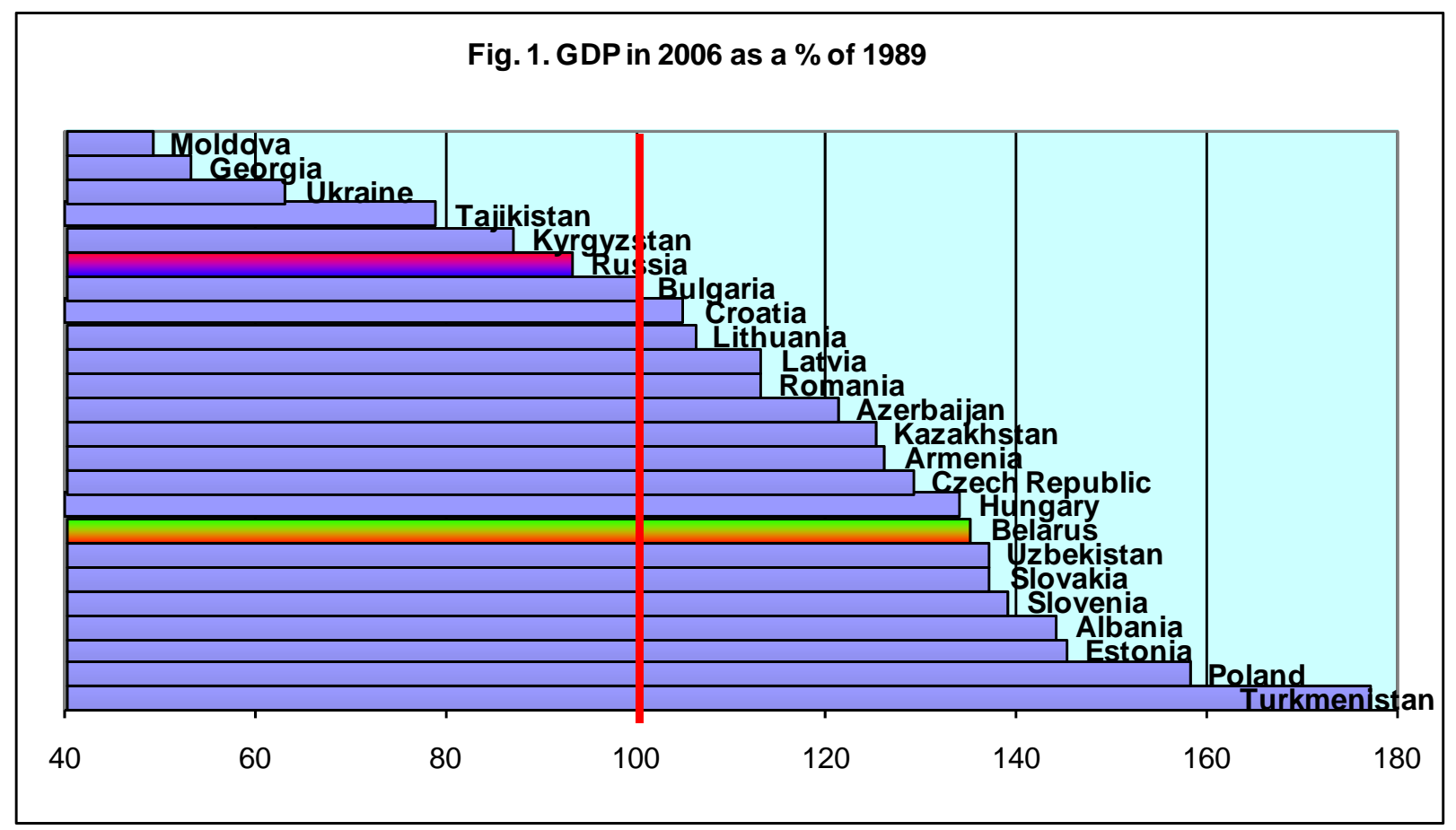

Source: EBRD (Transition Report, various years).

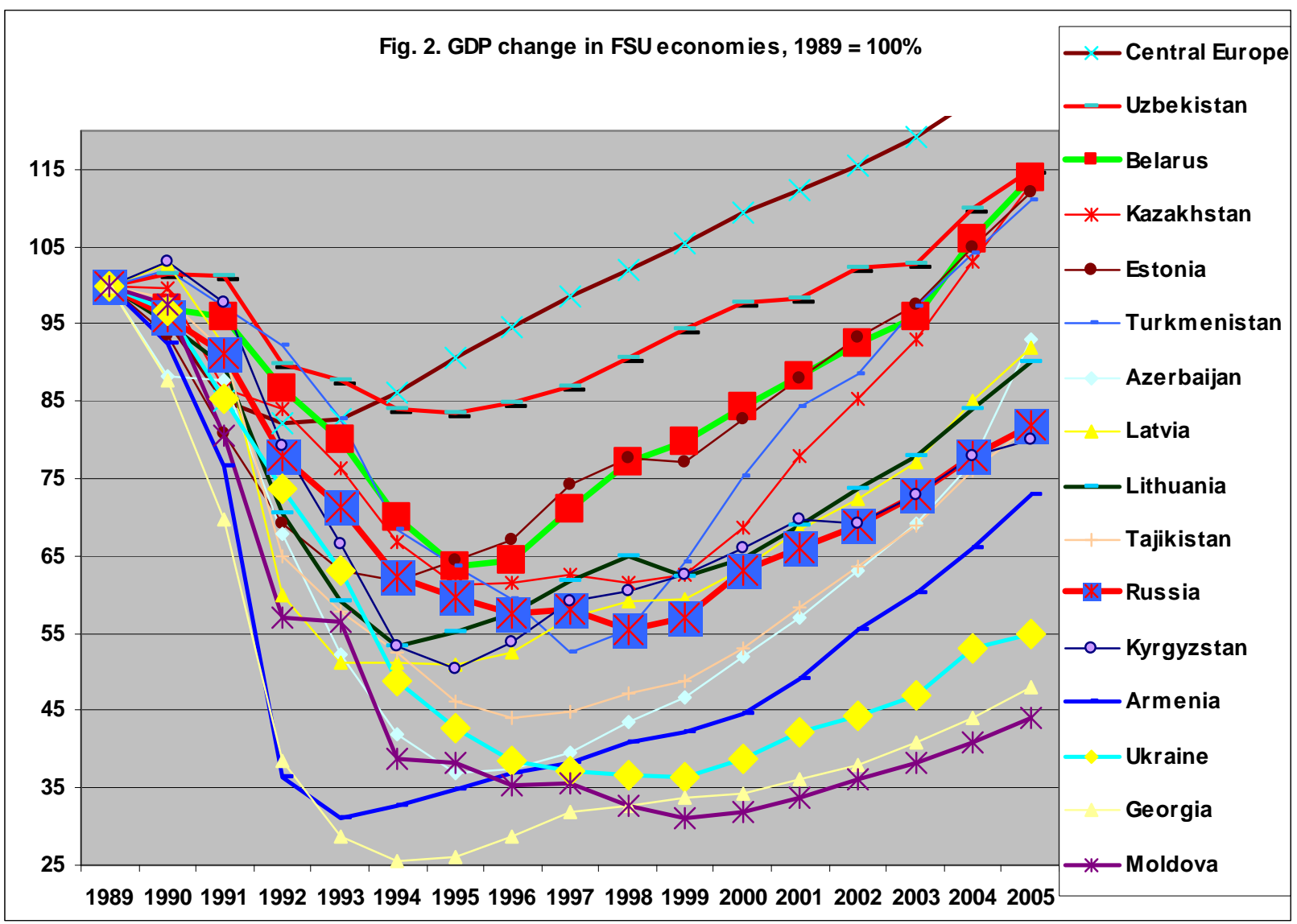

Source: EBRD (Transition Report, various years). 


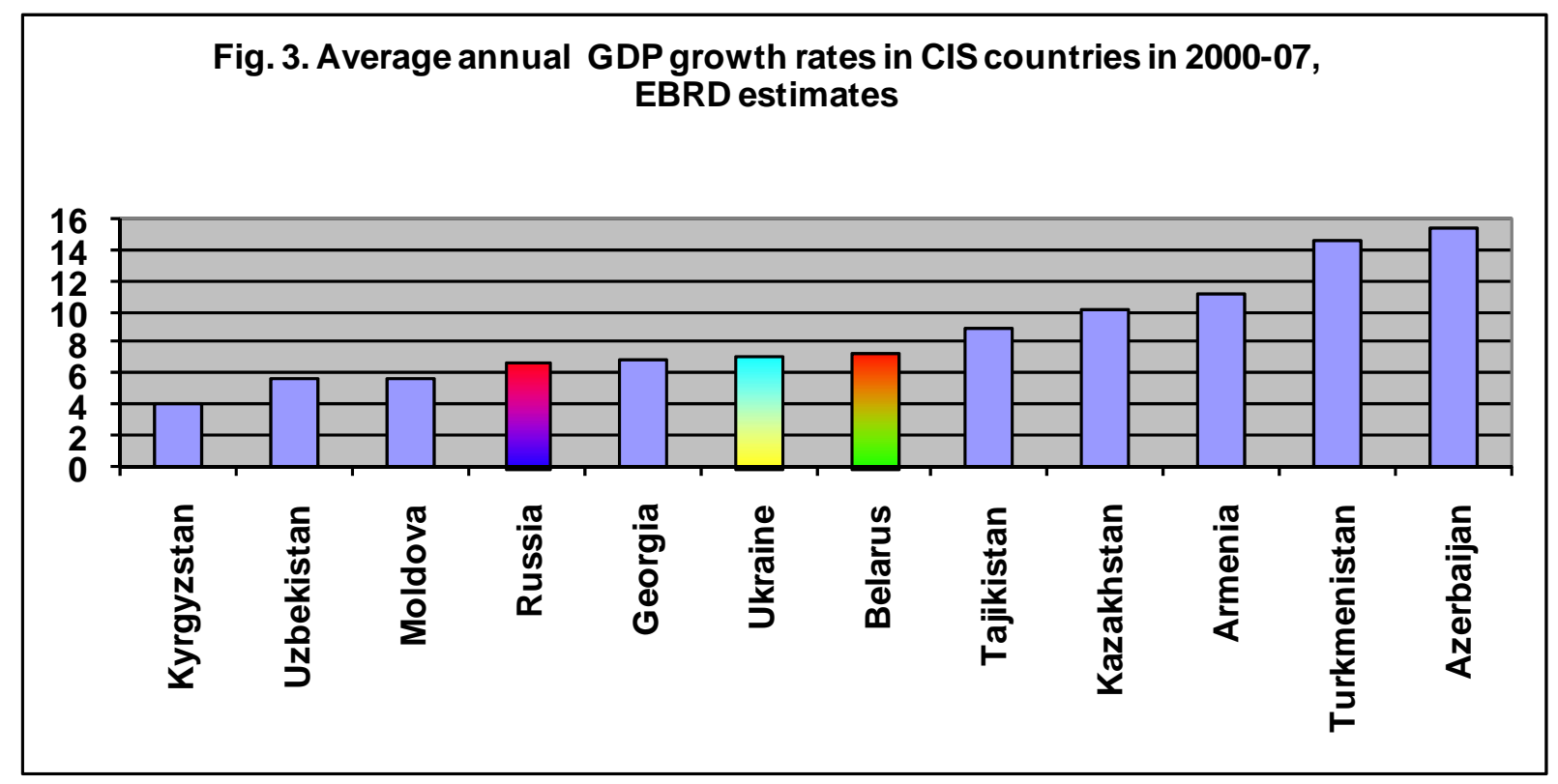

Source: EBRD (Transition Report 2007).

Fig. 4. Private sector share in GDP, \%

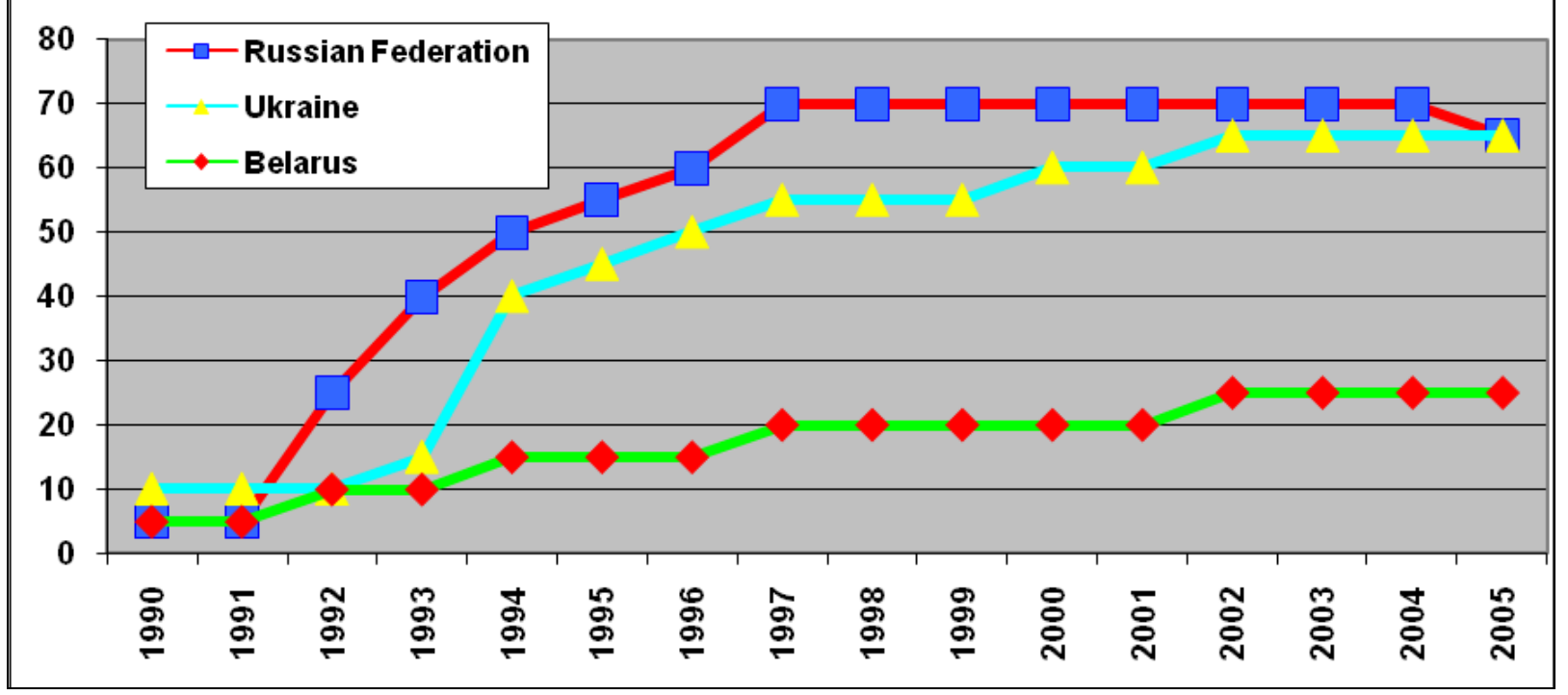

Source: EBRD (Transition Report 2007).

Among the 'other', nonorthodox success stories in the postcommunist world are fuel rich Turkmenistan, Kazakhstan and Azerbaijan; fuel self-sufficient Uzbekistan and Vietnam, and fuel importers Belarus and China. All these countries are non-democratic, but some are quite liberal economically (Kazakhstan), whereas others carry out heavy handed industrial policy and did not even bother to privatize state enterprises in nearly two decades of economic reforms (the share of private sector in GDP in Uzbekistan 45 per cent; in Belarus 25 per cent, Figure 4). 
Not to speak about the example of Cuba, a country that still (despite all recent reforms) has a centrally planned economy, but grows faster than Latin American countries on average (Figure 5). In addition, with the life expectancy of 77 years, one of the highest in Latin America (only Costa Rica has a similar indicator) and among communist and post-communist countries, Cuba has a very high human development index, higher than most FSU republics and many EE countries (Figure 6).

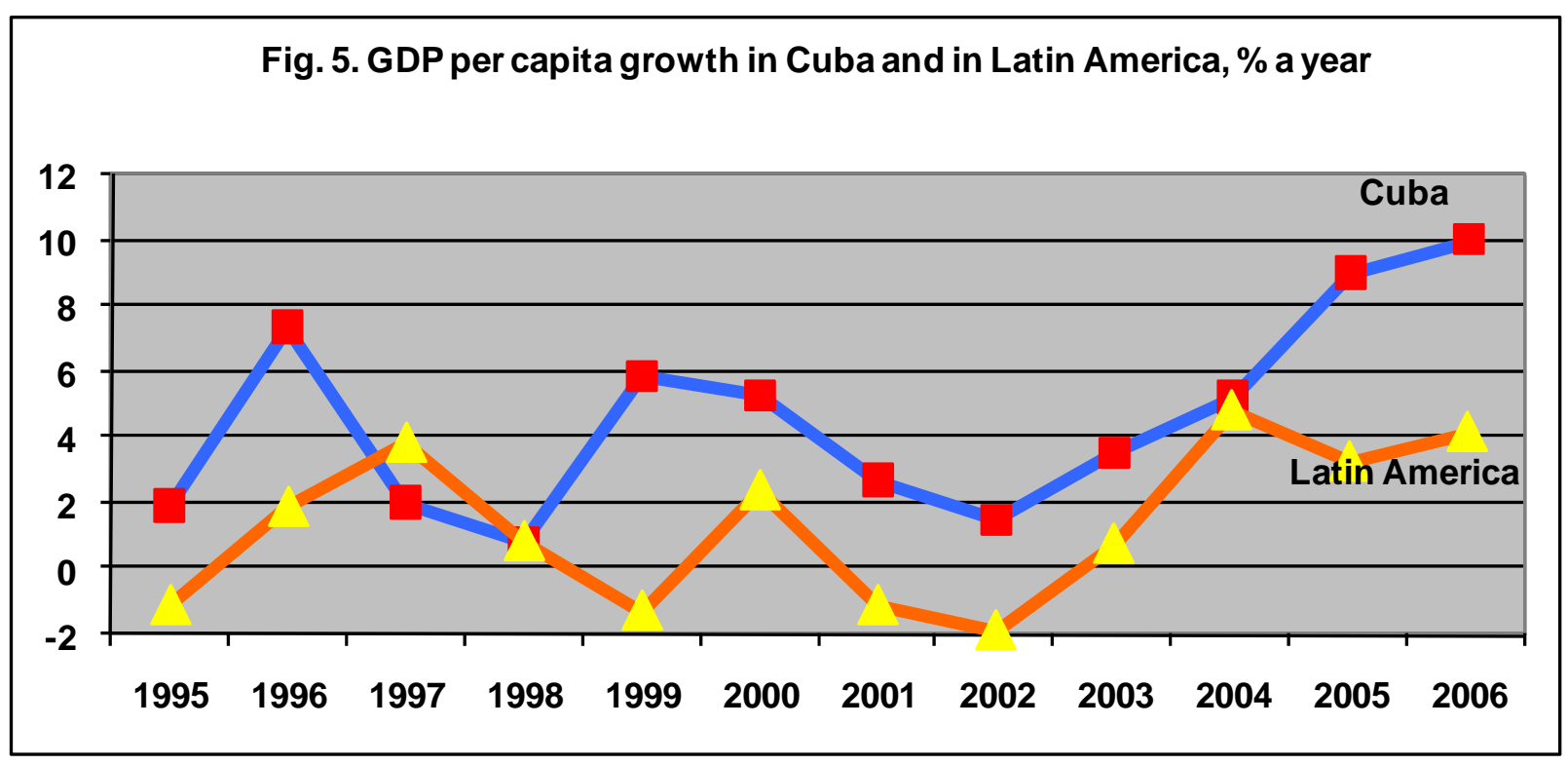

Source: World Bank (2007).

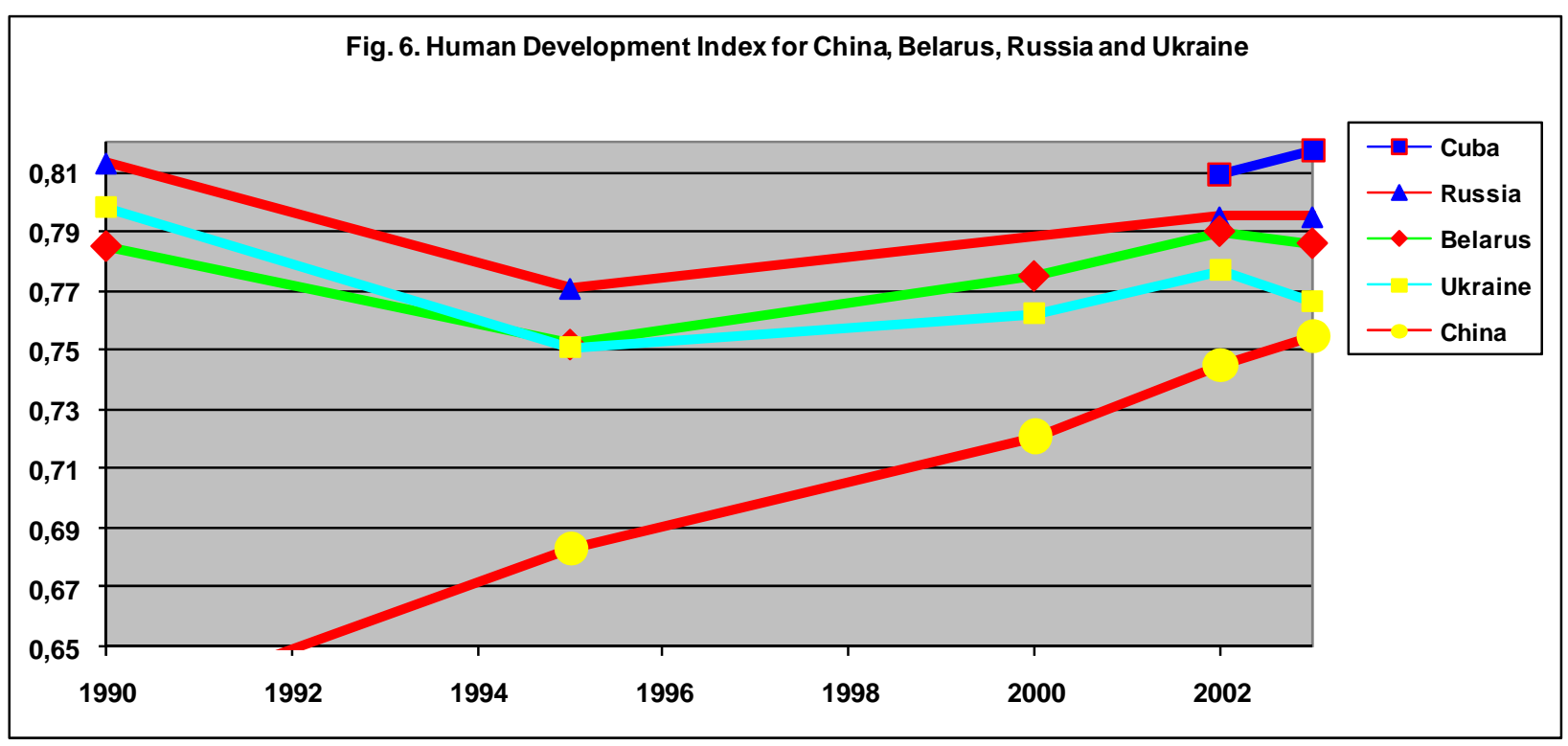

Source: UNDP (2007).

\section{Stages of development and optimal policy}

One explanation of the different foundations of success is that good policies are context dependent. There is a large body of literature that has emerged in recent years, which questions the universality of recipes for reform. Simply put, this literature states that what may be good for a relatively developed country with reasonable institutions is not 
necessarily good for countries that are farther away from the technological frontier and where corruption flourishes. Even the simple enumeration of the areas where marketoriented reforms are found to be detrimental for less developed countries is quite impressive: free international trade and migration of skilled labour, elimination of subsidies to producers and promotion of competition, liberalization of capital flows and deregulation of domestic financial markets. The general conclusion of such studies is that developing countries should not embark blindly on market friendly policies/reforms, even if the latter proved to be beneficial in more advanced countries. On the contrary, in other areas, such as the protection of intellectual property rights or environmental standards, western regulatory requirements are perceived to be too strict for poorer countries.

The argument in both cases is that most western countries 100 years ago did not have either laissez faire markets, or today's strict standards of protection of environmental and human rights. Advocating the acceptance of these standards in less wealthy parts of the world, and even threatening developing countries with economic sanctions in case they refuse to accept such standards, the west, whatever the good intentions may be, de facto undermines the competitiveness of poorer countries and preserves their backwardness. There are even accusations of a double standard (when the west was industrializing, it was not maintaining these standards) and 'kicking away the ladder' (after the west got rich through the exploitation of colonies and child labour, it does everything to slow down the growth of 'the other world', Chang 2002).

Two recent papers by Acemoglu, Aghion and Zilibotti (2002a, 2002b) offer a model to demonstrate the dependence of economic policies on the distance to the technological frontier. These papers consider policies with respect to hiring managers (life-time employment versus temporary contracts) and vertical integration and size of firms, ${ }^{2}$ but the general principle can be extended to quite a number of areas, from trade liberalization to policies with respect to migration. Optimal policies do differ at various stages of development and the art of a policymaker is to shift the gears at the appropriate time. For instance, even if private property is more efficient than state property in developed countries, government-controlled business entities can still be superior to privatized businesses in a poor institutional environment, when contracts are poorly enforced, especially in areas where resource rent is generated (Chang 2007).

It was also shown that policies in a variety of areas (trade protectionism, 'exchange rate protectionism'-accumulation of foreign exchange reserves, technological imitation versus indigenous innovation, protection of IPRs (intellectual property rights), industrial concentration versus development of small businesses, bank-based versus market-based financial system, liberalization of capital account, including FDI, migration of skilled/unskilled labour) do depend on the level of development (distance to technological frontier) and on the quality of institutions: cross-country regressions allow

2 The authors assume that a change of a country's technological level is equal to the weighted sum of technological change due to imitations and innovations. The speed of imitation is fixed whereas the speed of innovation is larger for more advanced economies. The experience of new managers is most important for imitations, whereas their talents are crucial for innovation. If the distance to the technological frontier is large, the economy would be better off giving managers long-term contracts that would lead to imitation and investment-based growth. But once the economy approaches the technological frontier and innovation yields greater returns than imitation, the life-time employment system should be replaced by the competitive selection. 
to reveal the thresholds in per capita GDP and institutional indicators that separate positive and negative influence of various policies on growth (Polterovich and Popov 2005, 2006). 3

The same is true with regards to political regimes conducive to growthdemocratization, unfortunately, leads to the weakening of institutional quality and lower growth, if carried out in countries with poor initial tradition of the rule of law and large resource wealth (Polterovich and Popov 2007; Polterovich, Popov and Tonis 2007, 2008).

In general, a theory that prescribes a particular mix of policies to countries at different levels of development and with different institutional quality (different levels of human capital, different endowment with natural resources, etc.) seems to be the new emerging conventional wisdom that lays the new foundations of new development economics. In a sense it is like filling the cells of the economic periodic table-once all initial conditions are factored in, a unique set of policies can be prescribed. The idea in its general form seems to be very intuitive and even trivial, especially to non-economists, but once it comes to particular policy prescriptions (for instance, trade protection can stimulate growth in countries with low level of development, but relatively good institutional capacity), the debates intensify.

Such an approach may explain why particular postcommunist countries at a lower stage of development and with poor tradition of the rule of law (Azerbaijan, Belarus, China, Kazakhstan Turkmenistan, Uzbekistan, Vietnam) succeeded under authoritarian regimes and by pursuing economic policies that often were not at all liberal and differed a lot from the shock therapy treatment that was used in central Europe and is credited for its success. And it can also explain why their more democratic and more economically liberal counterparts with similar levels of development and similar quality of institutions (Armenia, Georgia, Kyrgyzstan, Moldova, Mongolia, Russia, Tajikistan, Ukraine) did worse, sometimes much worse (Figures 1 and 2).

\section{Path dependence and missing ingredients}

Still, this is a universal scheme-less straightforward than the Washington consensus, but a universal one nonetheless. Another factor explaining successful performance of countries that pursued different policies is that there is more than one route to success. And the routes are path dependent. As Lenin wrote in 1916, 'all nations will reach socialism, that is inevitable, but none in exactly the same way'. It may well be that similar countries and even the very same country can achieve what is vaguely labelled 'success' by taking different paths that lead to the same final destination and that are not very different in terms of costs and benefits along the way.

3 Regression equations have the general form: GROWTH $=$ Control Variables $+\mathbf{P}(a-b \mathbf{X})$, where $\mathbf{P}$ is the policy variable, for instance, degree of trade protection, and $\mathbf{X}$ is per capita GDP and/or institutional indicator, for instance, government effectiveness. There is a threshold level of per capita GDP and/or the quality of institutions: before this level is reached, the impact of particular policy on growth is positive, after it is exceeded, the impact turns into negative. 
As a first approximation, it may be appropriate to distinguish between market-led and state-led economic systems. If for a given level of economic development there is one and only one optimal combination of state and markets, there should be countries on both sides of the optimal trajectory: leaning to the market, like Sub-Sahara Africa (SSA) and Latin America (LA, with the exception of Cuba, of course), South Asia (SA) and Commonwealth of Independent States (CIS) today, and leaning towards the state, like East Asia (EA) and communist countries before the 1990s. If the former had a lot of deregulation and markets but not sufficient state capacity, the latter had a lot of state capacity but heavily regulated and poorly liberalized markets or sometimes no markets at all. Whereas the major problem in the former was state failure, in the latter it was market failure.

A close analogy is that by Wassily Leontief (1974), who notes that an economy using the profit motive but without planning is like a ship with a sail but no rudder. It may move rapidly, but cannot be steered and might crash into the next rock. A purely planned economy that has eliminated the profit motive is like a ship with a rudder but no sail. It could be steered exactly where one wants it to go, if only it moved. To move forward while avoiding dangerous pitfalls, an economy needs both some reliance on the profit motive and some planning, a sail and a rudder.

Similarly, Holmes (1997) claims that the major lesson to be learned by western democracies from recent Russian developments is exactly the one about the crucial importance of the state institutions: whereas the Soviet Union has proven that nonmarket economic system with the strongest state cannot be efficient, Russia today is proving that the market without strong state degrades to the exchange of unaccountable power for the untaxable wealth leading to economic decline.

To put it differently, reforms that are needed to achieve success are different for countries with different backgrounds. Manufacturing growth is like cooking a good dish-all needed ingredients should be in the right proportion; if only one is under- or overrepresented, the 'chemistry of growth' will not happen. Fast economic growth can materialize in practice only if several necessary conditions are met at the same time. Rapid growth is a complicated process that requires a number of crucial inputsinfrastructure, human capital, even land distribution in agrarian countries, strong state institutions, economic stimuli, among other things. Once one of these crucial necessary ingredients is missing, the growth just does not take off. Rodrik, Hausmann and Velasco (2005) talk about 'binding constraints' that hold back economic growth; finding these constraints is the task of 'growth diagnostics'. In some cases, these constraints are associated with the lack of market liberalization, in others, with the lack of state capacity or human capital or infrastructure.

Why economic liberalization worked in central Europe, but did not work in SSA and LA? The answer, according to the outlined approach, would be that in central Europe the missing ingredient was economic liberalization, whereas in SSA and LA there was a lack of state capacity, not the lack of market liberalization. Why liberalization worked in China and central Europe and did not work in CIS? Because in the CIS it was carried out in such a way as to undermine the state capacity - the precious heritage of socialist past-whereas in central Europe, and even more so in China, the state capacity did not decline substantially during transition. 
Have a closer look at the Chinese case. It is important to realize that rapid catch-up development of post-reform period is due not only to and even not so much to economic liberalization and market-oriented reforms. The preconditions for the Chinese success of the recent 30 years were created mostly in the preceding period of 1949-76. In fact, there would be no exaggeration to claim that without the achievements of Mao's regime, the market-type reforms of 1979 and beyond would never have produced the impressive results that they actually did. In this sense, economic liberalization in 1979 and beyond was only the last straw that broke the camel's back. The other ingredientsmost importantly, strong institutions and human capital-had already been provided by the previous regime. Without these other ingredients, liberalization alone in different periods and different countries was never successful and sometimes counterproductive, as in Sub-Sahara Africa in the 1980s.

Market-type reforms in China in 1979 and beyond brought about the acceleration of economic growth because China already had an efficient government that was created by CPC (Communist Party of China) after liberation, but which had been missing for centuries before that 4 ( $\mathrm{Lu} \mathrm{1999).} \mathrm{Through} \mathrm{the} \mathrm{party} \mathrm{cells} \mathrm{in} \mathrm{every} \mathrm{village} \mathrm{the}$ communist government in Beijing was able to enforce its rules and regulations all over the country more efficiently than Qing Shi Huangdi and any emperor since then, not to speak of the Guomindang regime (1912-49). While in the late nineteenth century the central government had revenues equivalent to only 3 per cent of GDP (against 12 per cent in Japan right after the Meiji restoration) and under Guomindang government they increased only to 5 per cent of GDP, Mao's government left state coffers with revenues equivalent to 20 per cent of GDP to Deng's reform team. Chinese crime rate in the 1970s was among the lowest in the world, Chinese shadow economy was virtually nonexistent, corruption was estimated by Transparency International even in 1985 as the lowest in the developing world. In the same period, during the 'clearly the greatest experiment in the mass education in the history of the world' (UNESCO-sponsored 1984 Report) literacy rates in China increased to from 28 per cent in 1949 to 65 per cent by the end of the 1970s (41 per cent in India).

To put it differently, by the end of the 1970s, China had virtually everything that was needed for growth except some liberalization of markets-an element introduced much easier than human capital or institutional capacity. But even this seemingly simple task, economic liberalization, required careful management. Many former Soviet republics that also had strong institutions and human capital and hence enjoyed good starting conditions for reform, were not able to carry out economic liberalization without destroying state capacity.

\section{Liberalization without destruction of state institutions}

Searching for the reasons of the successful performance of China, experts point to the household responsibility system and to township and village enterprises (TVEs), to special economic zones (SEZs) and to one-child policy, to FDI and to connections with huaqiao (overseas Chinese). But other countries tried more than once to replicate all

4 To a lesser extent it is true about India: market-type reforms in the 1990s produced good results because they were based on the previous achievements of the import substitution period (Nayyar 2006). 
these elements of Chinese policy-and generally failed. Not only because they did not have the preconditions in the form of physical infrastructure, human capital and working institutions (the USSR had all these), but because these preconditions for successful liberalization were often not preserved during the reforms. The trick of transition, as is evident post factum, was not to carry out economic liberalization, but to carry it out in such a way as not to throw out the baby with the bathwater, not to squander the precious achievements of the previous communist period in the form of strong institutions. Even though government spending dropped, income inequalities rose and crime rates increased, China generally did not squander this heritage, 5 whereas Russia and most other CIS states did.

Out of the 30 transition economies, only several were spared the sharp reduction of the share of government revenues/spending in GDP during transformation-Estonia, Vietnam and central European countries (Czech Republic, Hungary, Poland, Slovak Republic, Slovenia); government expenditure/GDP ratios also fell in Uzbekistan and Belarus but less dramatically than in other countries (Figure 7). It is easy to notice that these countries are exactly the ones that exhibited the most favourable GDP dynamics: in central Europe the 2000 GDP surpassed the pre-recession level of 1989, whereas Uzbekistan, Belarus and Estonia (exactly in this order) came closer than other Soviet republics to the restoring pre-transition GDP level, and Vietnam experienced no transformational recession at all.

China seems to be an exception from this rule, since there was no transformational recession in China, but the share of government spending in GDP fell from 35 per cent in 1978 to 13 per cent in the mid 1990s. However, first, the major decrease occurred in

5 In the post 1979 reform period, the Chinese model of economic growth is based on principles that have nothing to do with the Washington or even post-Washington consensus. Responsible macroeconomic policies (no high inflation) is about the only principle of the Washington consensus that China has adhered to after 1979 (as well as before 1979), whereas with respect to other fundamental principles (fast deregulation and liberalization of prices and markets, downsizing of the government, privatization, opening up of the economy) Chinese policy was not only different, but exactly the opposite of neoliberal prescriptions (Popov 2007b). Since 1979 the Chinese economic model is based on:

- Gradual democratization and preservation of the one party rule in China allowed to avoid institutional collapse, whereas in Russia institutional capacity was adversely affected by the shock-type transition to democracy (Polterovich and Popov 2007);

- Gradual market reforms-‘dual track price system’ (co-existence of the market economy and centrally planned economy for over a decade), 'growing out of socialism' (no privatization until 1996, but creation of the private sector from scratch), non-conventional forms of ownership and control (TVEs);

- Industrial policy-strong import substitution policy in 1949-78 and strong export-oriented industrial policy thereafter with such tools as tariff protectionism (in the 1980s import tariffs were as high as up to 40 per cent of the value of import) and export subsidies (Polterovich and Popov 2005);

- Macroeconomic policy—not only in traditional sense (fiscal and monetary policy), but also exchange rate policy: rapid accumulation of foreign exchange reserves in China (despite positive current and capital account) led to the undervaluation of yuan, whereas Russian ruble became overvalued in 1996-98 and more recently, in 2000-08. Undervaluation of the exchange rate via accumulation of reserves became in fact the major tool of export-oriented industrial policy (Polterovich and Popov 2004). 


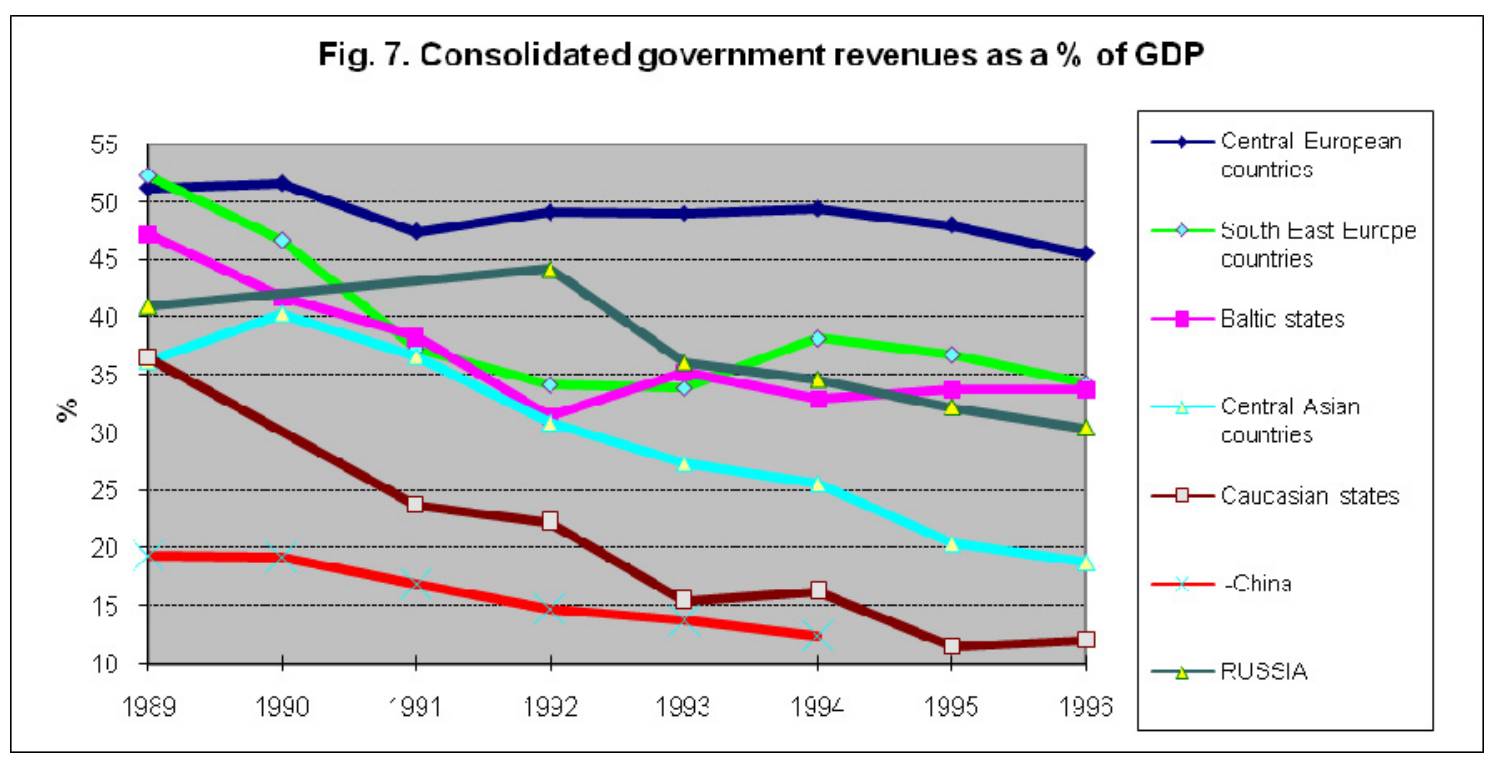

Source: Popov (2000).

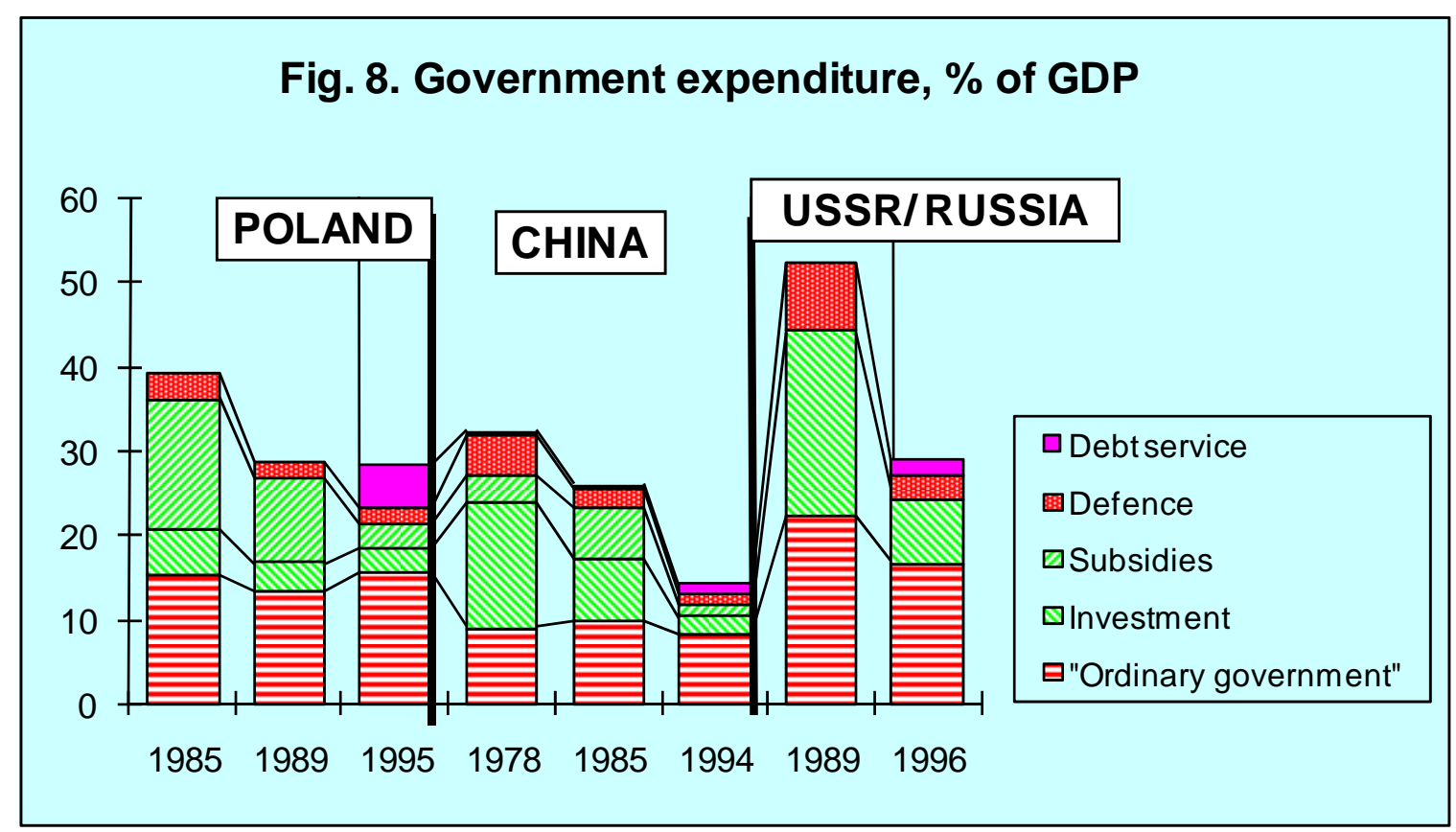

Source: Popov (2000).

the second half of the 1980s, whereas in the first stage of transition the government spending was growing pretty much in line with GDP. Second, the decrease in the share of state expenditure was a controlled process, i.e., it occurred due to the initiative of the government itself, not despite its efforts. And third, expenditure for the 'ordinary government' (excluding subsidies, investment and defence spending) grew in line with GDP. Finally, the share of state expenditure in GDP in China has been increasing (about 20 per cent in 2007) since 1995.

Three major patterns of change in the share of government expenditure in GDP generally coincide with the three major archetypes of institutional developments, and even broader, with three most typical distinct 'models' of transition (Figure 8): 
- under strong authoritarian regimes (as in China), cuts in government expenditure occurred at the expense of defence, subsidies and budgetary financed investment, while expenditure for 'ordinary government' as a percentage of GDP remained largely unchanged (Naughton 1997);

- under strong democratic regimes (Poland) budgetary expenditure, including those for 'ordinary government', declined only in the pre-transition period, but increased during transition itself; and finally,

- under weak democratic regimes (Russia) the reduction of the general level of government expenditure led not only to the decline in the financing of defence, investment and subsidies, but to the downsizing of 'ordinary government', which undermined and, in many instances, led even to the collapse of the institutional capacities of the state.

While in China total budgetary expenditures and that for 'ordinary government' were much lower than in Russia and Poland, they were sufficient to preserve the functioning institutions since the financing of social security from the government budget was traditionally low. In Russia, however, although expenditure for ordinary government seems to have been not that much lower than in Poland, the pace of its reduction during transition exceeded that of GDP: to put it differently, given the various patterns of GDP dynamics, while in Poland 'ordinary government' financing grew by about one-third in real terms in 1989-95/6 (and nearly doubled in China), it fell in Russia by about twothirds! The Russian pattern of institutional decay proved to be extremely detrimental for investment, and for general economic performance.

In most CIS states the reduction of the government expenditure occurred in the worst possible way: it proceeded without any coherent plan and did not involve a reassessment of government commitments. Instead of completely shutting down some government programmes and concentrating limited resources on the others with an aim to raise their efficiency, the government kept all programmes half-alive, half-financed, and barely working. This led to the slow decay of public education, health care, infrastructure, law and order institutions, fundamental R\&D, etc. Virtually all services provided by the government-from collecting custom duties to regulating street traffic_-became the symbol of notorious economic inefficiency.

Education and health care had been free in the Soviet Union, but now these services are provided mostly for a fee and their quality is way below Soviet standards. Life expectancy declined from 70 years in 1987 to 65 years in 2006 (against 73 years in China). Criminalization of the country made a mockery out of the concept of the law and order: murder rate surged from ten in the late 1980s to about 30 per 100,000 of the population in the second half of the 1990s, as compared to 1-2 in eastern and western Europe, Japan and China, Israel and Mauritius. Only Columbia and South Africa had a higher murder rate than Russia, while Brazil and Mexico had a murder rate of about half Russia's level. Even the US rate, the highest among western nations at 6-7 per 100,000 people, pales in comparison.

In 1980-85, the Soviet Union was placed in the middle of a list of 54 countries rated according to their level of corruption, with a bureaucracy cleaner than that of Italy, Greece, Portugal, South Korea and practically all the developing countries. In 1996, after the establishment of a market economy and the victory of democracy, according to 


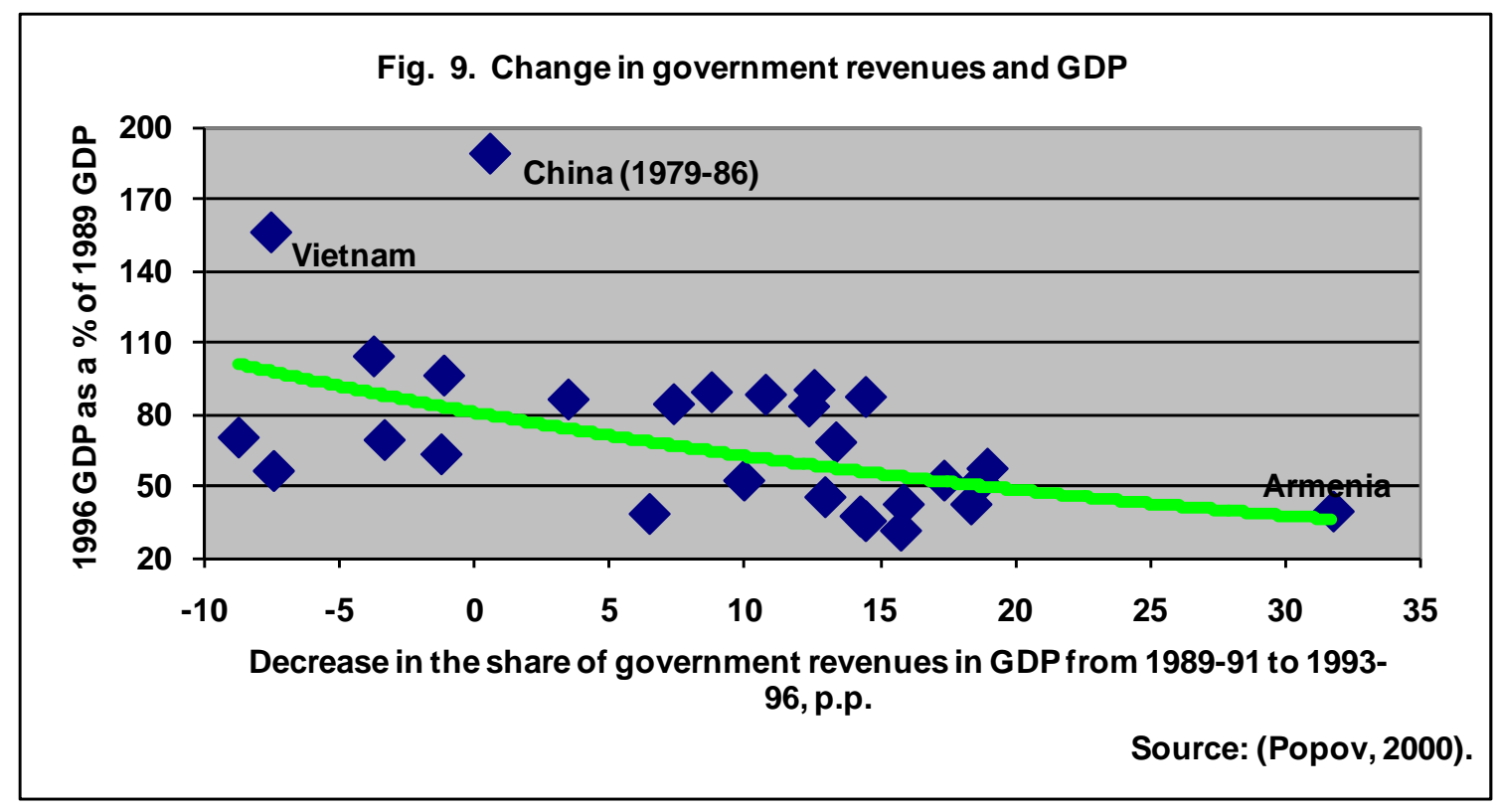

Source: Popov (2000).

Transparency International, Russia came in 48th in the same 54-country list, between India and Venezuela. In 2005 Russia fell below India. The shadow economy estimated at 10-15 per cent of GDP in the late 1980s expanded to about 40 per cent by the mid 1990s.

This argument is not about the optimal size of the state (a widely discussed issue in economics). It is about the dismantling of the state-unprecedented in economic history - that occurred in Russia and some other former Soviet republics in such a short period of time in the early 1990s. Simply put, if crime, income inequality, poverty and corruption are on the rise, the state needs more money, not less, to bring these unfavourable developments to a halt.

In Kolodko's words, 'there can be no doubt that during the early transition there was a causal relationship between the rapid shrinkage in the size of government and the significant fall in output' (Kolodko 2000: 259). If the indicator of change in the share of state expenditure in GDP is added into regressions explaining output change during transition, it remains statistically significant even after factoring in such conventional variables as initial conditions (per capita GDP before transition, distortions in the industrial structure and in trade patterns inherited from central planning), the impact of wars, macroeconomic stability (inflation rates); see Popov 2000, 2007a. But even from Figure 9 it is apparent that the decline in the share of government revenues in GDP was correlated with the decline in output during the transformational recession.

Virtually everywhere in the transition world the reduction of government spending was accompanied by the increase in the share of the shadow economy. Equally unpleasant was the accompanying increase in income inequalities. Only countries with the lowest decline of the share of state spending in GDP (central Europe, Estonia, Uzbekistan, Belarus) managed to keep the increases in inequalities within reasonable limits. In turn, the increase in income inequalities had a detrimental effect on economic growth because it contributed to social tensions and worsened investment climate (Alesina and Rodrik 1994; Alesina and Perotti 1996) and because it created lobbies that opposed structural 
reforms and macrostabilization (Fernandez and Rodrik 1991; Persson and Tabellini 1994). Besides, social inequalities created grounds for macroeconomic populismredistribution of funds from winners to losers, from competitive to non-competitive sectors, from rich to poor (Kaufman and Stallings 1991): the greater the income inequalities, the stronger was the lure to redistribute the economic pie instead of increasing it.

In general, from all points of view, the dynamics of the government expenditure during transition seems to have been by far the more important factor of successful transformation than the speed of reforms. Keeping the government big does not guarantee favourable dynamics of output, since government spending has to be efficient as well. However, the sharp decline in government spending, especially for the 'ordinary government', is a sure recipe to ensure the collapse of institutions and the fall in output accompanied by the growing social inequalities and populist policies.

When real government expenditure fall by 50 per cent and more-as happened in most CIS and south-east European states in the short period of time, just in several yearsthere are practically no chances to compensate the decrease in the volume of financing by an increased efficiency of institutions. As a result, the ability of the state to enforce contracts and property rights, to fight criminalization and to ensure law and order in general falls dramatically.

Thus, the story of the successes and failures of transition is not really the story of consistent shock therapy and inconsistent gradualism. The major plot of the postsocialist transformation 'novel' is the preservation of strong institutions in some countries (very different, in other respects, from central Europe and Estonia to China, Uzbekistan and Belarus) ${ }^{6}$ and the collapse of these institutions in the other countries. At least 90 per cent of this story is about the government failure (strength of state institutions), not about the market failure (liberalization).

\section{Conclusions}

To summarize, there are at least three reasons why many transition economies succeeded by pursuing policies that are so different from radical economic liberalization (shock therapy) that is normally credited for the economic success of central European countries.

First, optimal policies are context dependent, they are specific for each stage of development and what worked in Slovenia cannot be expected to work in Mongolia. Second, even for countries at the same level of development, reforms needed to stimulate growth are different; they depend on the previous history and on the path

6 Countries like Belarus and Uzbekistan fall into the same group with central European countries and Estonia-with small reduction of state expenditure as a per cent of GDP during transition, good quality of governance, little bribery, small shadow economy and low state capture index (Hellman, Jones and Kaufmann 2000). In 2005, Belarus and Slovak Republic were the only two countries out of 25 surveyed in EE and FSU (BEEPS-Business Environment and Economic Performance Survey), where significant improvement was registered in 2002-05 in all seven areas of economic governance (judiciary, fighting crime and corruption, customs and trade, business licensing and permits, labour regulations, tax administration) (EBRD 2005). 
chosen. The reduction of government expenditure as a share of GDP did not undermine significantly the institutional capacity of the state in China, but in Russia and other CIS states it turned out to be ruinous. It is the growth diagnostics that should reveal the missing ingredient for economic growth. Finally, third, and most important, introducing this 'missing ingredient' should not result in the destruction of other preconditions for growth. The art of the policymaker is to create markets without causing the government failure, as has happened in many CIS countries.

\section{References}

Acemoglu, D., P. Aghion, and F. Zilibotti (2002a). 'Distance to Frontier, Selection, and Economic Growth’. Available at: www.post.economics.harvard.edu/faculty/ aghion/ papers/Distance_to_Frontier.pdf

Acemoglu, D., P. Aghion, and F. Zilibotti (2002b). 'Vertical Integration and Distance to Frontier'. Available at: www.post.economics.harvard.edu/faculty/aghion/ papers/vertical inte-gration.pdf

Alesina, A. and D. Rodrik (1994). 'Distributive Politics and Economic Growth'. Quarterly Journal of Economics, 109 (2): 465-90;

Alesina, A., and R. Perotti (1996). 'Income Distribution, Political Instability, and Investment'. European Economic Review, 40 (6): 1203-28.

Chang, H.-J. (2002). Kicking Away the Ladder. Cambridge: Cambridge University Press.

Chang, H.-J. (2007). 'State Owned Enterprise Reform'. UN DESA National Development Strategies Policy Note. Available at: www esa.un.org/techcoop/ documents/PN_SOEReformNote.pdf.

EBRD (various years). Transition Report. London: EBRD. Available at: www.ebrd.com/pubs/econo/series/tr.htm

Fernandez, R., and D. Rodrik (1991). 'Resistance to Reform: Status Quo Bias in the Presence of Individual Specific Uncertainty’. American Economic Review, 81 (5): 1146-55.

Fukuyama, F. (2007). 'Development and the Limits of Institutional Design'. In N. Dinello and V. Popov (eds), Political Institutions and Development. Failed Expectations and Renewed Hopes. Cheltenham: Edward Elgar.

Hausmann, R., J. Hwang, and D. Rodrik (2006). 'What You Export Matters'. NBER Working Paper. Cambridge, MA: National Bureau of Economic Research

Hellman, J,. G. Jones, and D. Kaufmann (2000). 'How Profitable Is Buying the State Officials in Transition Economies?'. Transition: The Newsletter about Reforming Economies, April: 8-11.

Holmes, S. (1997). 'What Russia Teaches Us Now: How Weak States Threaten Freedom'. The American Prospect, 33 (July-August): 30-9. 
Kaufman, R., and B. Stallings (1991). 'The Political Economy of Latin American Populism'. In R. Dornbush and S. Edwards (eds), Macroeconomics of Populism in Latin America. Chicago: University of Chicago Press.

Kolodko, G. W. (2000). From Shock to Therapy. Political Economy of Postsocialist Transformation. Oxford-New York: Oxford University Press.

Leontief, W. (1974). 'Sails and Rudders, Ship of State'. In L. Silk (ed.), Capitalism, the Moving Target. New York: Quadrangle Books, 101-4.

Lu, A. (1999). China and the Global Economy since 1840. New York: St. Martins Press.

Naughton, B. (1997). 'Economic Reform in China. Macroeconomic and Overall Performance'. In D. Lee (ed.), The System Transformation of the Transition Economies: Europe, Asia and North Korea. Seoul: Yonsei University Press.

Nayyar, D. (2006). 'India's Unfinished Journey. Transforming Growth into Development'. Modern Asian Studies, 40 (3): 792-832.

Persson, T., and G. Tabellini (1994). 'Is Inequality Harmful for Growth?' American Economic Review, 84 (3): 600-21.

Polterovich, V., and V. Popov (2004). 'Accumulation of Foreign Exchange Reserves and Long-Term Economic Growth'. In S. Tabata and A. Iwashita (eds), Slavic Eurasia's Integration into the World Economy. Sapporo: Slavic Research Center, Hokkaido University. Available at: www.nes.ru/\%7Evpopov/documents/exchange \%20rate-GrowthDEC2002withcharts pdf .

Polterovich, V., and V. Popov (2005). 'Appropriate Economic Polices at Different Stages of Development'. Moscow: New Economics School. Available at: www.server.carleton.ca/ vpopov/documents/STAGES-MAY-2005-English.pdf .

Polterovich, V., and V. Popov (2006). 'Stages of Development, Economic Policies and New World Economic Order'. Paper presented at the Seventh Annual Global Development Conference, January. St. Petersburg. Available at: www.server.carleton.ca/ vpopov/documents/NewWorldEconomicOrder.pdf .

Polterovich, V., and V. Popov (2007). 'Democratization, Quality of Institutions and Economic Growth’. In N. Dinello and V. Popov (eds), Political Institutions and Development. Failed Expectations and Renewed Hopes. Cheltenham: Edward Elgar Publishing.

Polterovich, V., V. Popov, and A. Tonis (2007). 'Resource Abundance, Political Corruption, and Instability of Democracy’. NES Working Paper 2007/73. Moscow: New Economic School.

Polterovich, V., V. Popov, and A. Tonis (2008). 'Mechanisms of Resource Curse, Economic Policy and Growth’. NES Working Paper 2008/000. Moscow: New Economic School.

Popov, V. (2000). 'Shock Therapy versus Gradualism: The End of the Debate (Explaining the Magnitude of the Transformational Recession)'. Comparative Economic Studies, 42 (1): 1-57. 
Popov, V. (2007a). 'Shock Therapy versus Gradualism Reconsidered: Lessons from Transition Economies after 15 Years of Reforms'. Comparative Economic Studies, 49 (1): 1-31.

Popov, V. (2007b). ‘China’s Rise in the Medium-Term Perspective: An Interpretation of Differences in Economic Performance of China and Russia since 1949'. História e Economia Revista Interdisciplinar, 3 (1-2).

Rodrik, D., R. Hausmann, and A. Velasco (2005). 'Growth Diagnostics, 2005'. Available at: www.ksghome.harvard.edu/ drodrik/barcelonafinalmarch2005.pdf .

UNDP (2007). Human Development Report, 2007. New York: Oxford University Press. Available at: www.hdr.undp.org/en/

World Bank (2007). World Development Indicators. Washington, DC: World Bank. 